\title{
Effects of S-Allyl Cysteine on Insulin Secretion: A Proposed Mechanism for its Anti-Hyperglycemic Effects
}

\author{
Mashkoor Ahmed Ansari ${ }^{1}$, Ashique Ali Arain*2, Qumar Zaman Phull ${ }^{3}$ and Abdul Rahim Memon ${ }^{4}$ \\ ${ }^{1}$ Department of Pharmacology, Bhittai Dental College MPS Sindh, Pakisthan \\ ${ }^{2}$ Consultant Family Physician, Assistant Professor, Department of Pharmacology, Isra University Hyderabad \\ ${ }^{3}$ Assistant Professor, Department of Pharmacology, Bilawal Medical College Jamshoro, Hyderabad \\ ${ }^{4}$ Department of Pharmacology, Isra University, Hyderabad
}

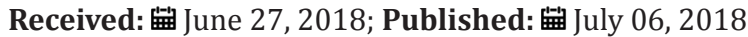

*Corresponding author: Ashique Ali Arain, Consultant Family Physician, Assistant Professor, Department of Pharmacology, Isra University Hyderabad

\begin{abstract}
Back ground: World is now moving towards the natural therapies due to many reasons not the topic of discussion. Majority of the available allopathic drugs are derived from the natural primary sources either from the animals or plants. Garlic and its derivative have been tested for many illnesses like hyperlipidemia, anti-platelet aggregation and HTN the current study focused on exploring the mechanism of glucose lowering properties of the S-allylcysteine, a garlic derivative.
\end{abstract}

Methodology: Rats were randomly divided into 3 groups with 10 rats in each group A was +ve control with no intervention, group B was kept -ve control given alloxon to induce hyperglycemia only, group C was given alloxon and S-allylcysteine . Blood sample were drawn after 7, 14 and 21 days to assess glucose random levels and plasma insulin concentrations. SPSS version22 using ANOVA as statistical technique was applied for data analysis.

Results: There was a significant reduction in blood glucose levels from $300+81.3 \mathrm{mg} / \mathrm{dl} 364+43.16 \mathrm{and} 218 .+36.38 \mathrm{mg} / \mathrm{dl}$ in S-allylcysteine treated group at 7,14 and 21 days respectively with p-value 0.0001 . Similarly serum insulin levels were also improved from $3.87+2.16,8.0+1.6 a n d$ $11.5+1.69 \mathrm{U} /$ Lin s-allyl cysteine group p-value 0.000021 .

Conclusion: Alloxon induced hypo-insulinemia was successfully corrected by S-allyl cysteine fitting it into insulin secretogogue category.

Keywords: Hyperglycemia; Alloxon; Insulin; SAC; Insulin Secretion; Vitamin B12; GI diseases; Glibenclamide; Non-Interventional; Anti-Metastatic; Insulin Resistance

\section{Introduction}

Diabetes Mellitus is one of the oldest diseases of the world called as jual bakar in the ancient times that means the cow's hunger disease. Strategies to tackle to this problem were adopted since then till now the well-established treatment regimen and guideline are available. Huge numbers of the drugs from insulin verities to oral agents have benefited the diabetic community a lot and the process of discovery of new options is still going on. Search processes for the prevention of diabetes from the cellular levels to the complications for setting the targeted goals for the medical practioners are on. The main problem with the allopathic drugs is their side effect profile weight gain and hypoglycemia with insulin and sulfonylurea's and renal failure and vitamin B12 deficiency with bigunides so on and so forth. The world is switching towards the natural remedies surprisingly with a lot of number of certifications in different alternative medicine practices from country to country. S-allyl cysteine is a garlic derivative has been worked upon by numerous researchers for its medicinal potentials e.g. antihypertensive, antiplatelet, anti-atherosclerosis, antihyperlipidemic and GI diseases [1-3].

Garlic and its derivatives has also been proved to possessantiproliferative, anti-metastatic effects and inhibition of apoptotic celldeath $[4,5]$. Alliin is the principal ingredient of garlic $(6-14 \mathrm{mg} /$ gram) and sulfide derivative of cysteine (S-allyl cysteine sulfoxide) which is store in garlic under low temperature and get converted from alliin to allicin also termed as garlicin by action of allinase $[6,7]$. Other components of garlic responsible forits effectsare fibers, selenium and polyphones. Garlic is water soluble so more stable but problem with intestinal absorption [8]. Garlicis cheaper and easily available worldwide previously we worked out its glucose lowering potential and found it comparable to glibenclamide $[9,10]$. Our 
present work was focused on to explore effects of s-allyl cysteine on insulin secretion by pancreas as a justified mechanism of action for these hypoglycemic properties.

\section{Methodology}

The animal model was set for experiments following ethical approval by ERC (ethical review committee) of Isra University. Rats of adult size (150-200grams) were purchase from animal house of institute. International protocols for animal handling for adopted regarding acclimatization, temperature, and day night cycle, water and food supply. Animals were divided in 3 groups A, B and C.Group was considered control group and kept as non-interventional, while Group B was induced with alloxon $120 \mathrm{mg} / \mathrm{kg}$ for destruction of pancreas and group C was co-administered S-allyl cysteine along with alloxon $120 \mathrm{mg} / \mathrm{kg} 10$. Blood sample were drawn at $1^{\text {st }}$, $2^{\text {nd }}$ and $3^{\text {rd }}$ weeks from tail, cardiac puncture and finally scarifying under anesthesia by cervical dislocation. Serum insulin levels were measured in Isra University Hospital Research lab.

\section{Statistical Analysis}

Mean and SD were compared between weeks for individual groups keeping $<0.05$ level of significance. ANNOVA was used on SPSS Version 22.

\section{Results}

There was a significant reduction in blood glucose levels from $300+81.3 \mathrm{mg} / \mathrm{dl} 364+43.16$ and $218 .+36.38 \mathrm{mg} / \mathrm{dl}$ in S-allylcysteine treated group at 7,14 and 21 days respectively with p- value 0.0001 . Serum insulin in group A, the control group remained unaffected at all levels $19.50 \pm 1.30 \mathrm{IU} / \mathrm{ml}$ at $1^{\text {st }} \mathrm{wk}, 20.5 \pm 1.92 \mathrm{IU} / \mathrm{ml}$ at $2^{\text {nd }}$ wk while $19.57 \pm 1.35 \mathrm{IU} / \mathrm{ml}$ at $3^{\text {rd }}$ wk with a non-significant p-value 0.28. Group B showed persistent low levels of insulin due to pancreatic damage with alloxon it was $3.17 \pm 1.22,3.87 \pm 1.45$ and $4.05 \pm 1.55 \mathrm{IU} / \mathrm{ml}$ at $1^{\text {st }}, 2^{\text {nd }}$ and $3^{\text {rd }}$ wks respectively with no significant improvement over three weeks (P-Value 0.35). However the serum insulin levels were found much improved in group $\mathrm{C}$ (S-allyl cysteine treated group) from $3.87+2.16,8.0+1.6$ and 11.5 $+1.691 \mathrm{IU} / \mathrm{ml}$, p-value 0.00021 (Table 1) (Figure 1).

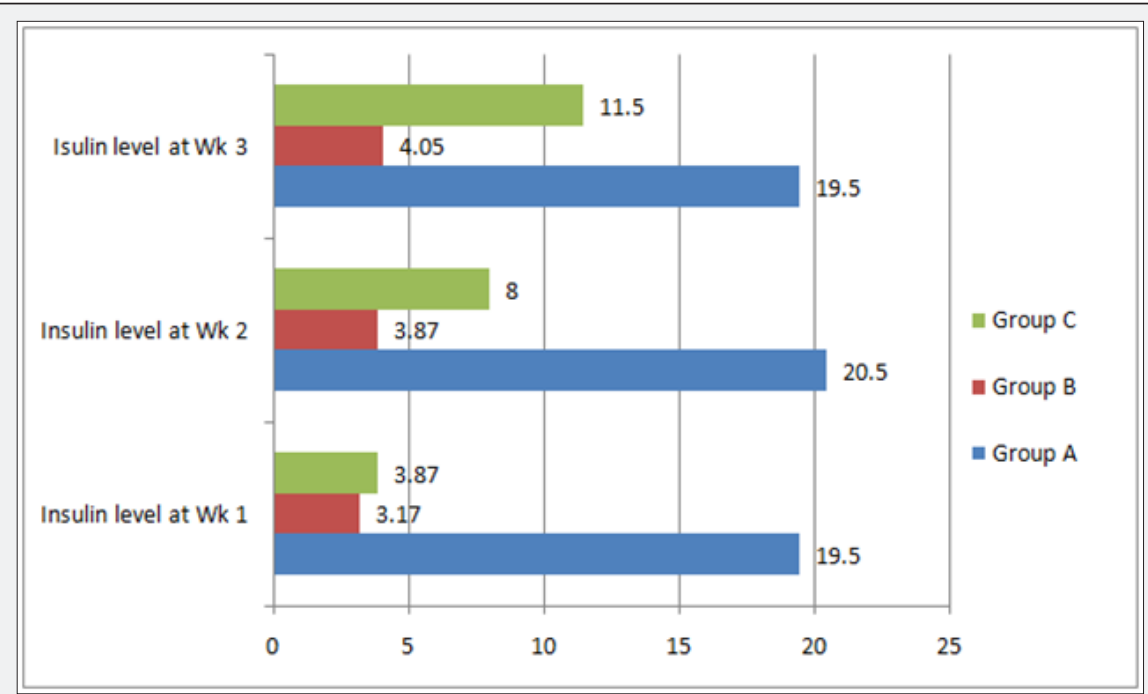

Figure 1: Bar charts of serum insulin changes over $3 \mathrm{Wks}$ in study groups.

Table 1: Mean of Serum Insulin levels changes over three Weeks.

\begin{tabular}{|c|c|c|c|c|}
\hline Groups & $\begin{array}{c}\text { Serum Insulin } \\
\text { IU/ml at Wk 1 }\end{array}$ & $\begin{array}{c}\text { Serum Insulin IU/ml at } \\
\text { Wk 2 }\end{array}$ & $\begin{array}{c}\text { Serum Insulin IU/ml at } \\
\text { Wk 3 }\end{array}$ & P-Value \\
\hline $\begin{array}{c}\text { Control } \\
\text { Group-A }\end{array}$ & $19.50 \pm 1.30$ & $20.5 \pm 1.92$ & $19.57 \pm 1.35$ & 0.28 \\
\hline $\begin{array}{c}\text { Alloxon } \\
\text { Group- B }\end{array}$ & $3.17 \pm 1.22$ & $3.87 \pm 1.45$ & $4.05 \pm 1.55$ & 0.35 \\
\hline $\begin{array}{c}\text { S-allylcysteine } \\
\text { Group-C }\end{array}$ & $3.87 \pm 2.16$ & $8.0 \pm 1.06$ & $11.50 \pm 1.69$ & 0.00021 \\
\hline
\end{tabular}

\section{Discussion}

Our current results were consistent to findings described by Augusta KT et al. [11] the difference was of in vivo and in vitro between the two [11]. Similarly SMA Shariatzadeh [12] also reported a $45 \%$ reduction in blood glucose levels in garlic treated rats which is parallel to what we report here however he induced diabetes with s streptozotoc in while we used allxon for this purpose and he did not monitor the insulin levels as well [12]. Sekh A N [13] also reported low glucose levels in garlic treated group supportive our findings [13]. Study of Fatma A A [14] proved similar increase in serum insulin levels following garlic oil therapy [14]. Few researchers also suggested multiple mechanism for glucose reduction by garlic along with insulin secretion that include increasing insulin sensitivity and GI flora regulation that interfere 
with carbohydrate absorption.6 Cheng-TzuLiu [15] also reported reduction of FBS and elevation of serum insulin as well as the reduction of serum oxidative stress [15]. It is proposed by Henriksen et al. [16] for increased oxidative stress to disturb the signal cascade of insulin secretion through p38 MAPK stimulation [16]. The expression of GLUT4 is repressed in adipo cytes by enhanced oxidative stress and impairs the binding of nuclear proteins to the IRL (insulin-responsive element) in the GLUT4 promoter according to Pessler-Cohen et al [17]. It is also demonstrated by Rajani Kanth et al [18] for garlic extract to attenuate the oxidative stress in intestinal as well as hepatic and tissues in diabetic rats along with improvement in GLUT4 expression as well as it reverses the insulin resistance [18].

\section{Conclusion}

S-allyl cysteine increases serum insulin levels that is responsible for its hypoglycemic property

\section{Recommendations}

Human studies are recommended in diabetic population using garlic supplementations along with the rational treatment options.

\section{References}

1. Suleria HAR, Masood SD, Nauman K, S Sultan, Ali RMA, et al. (2015) Garlic (Allium sativum): diet based therapy of 21st century-a review. Asian Pacific Journal of Tropical Disease 5(4): 271-278.

2. Rana SV, Pal R, Vaiphei K, Sharma SK, Ola RP (2011) Garlic in health and disease. Nutrition Research Reviews 24(1): 60-71.

3. Singh MR, Singh D, Srivastava S (2015) Formulation and evaluation of NLCS encapsulated with S-Allyl-L-Cysteine Sulfoxide for treatment of inflammatory bowel disease. Planta Medica 81(5): PP-17.

4. Marisol OI, Jorge MS, Martín EZM, Benjamín P, Roxana MM, et al. (2016) Aged garlic extract and S-allylcysteine prevent apoptotic cell death in a chemical hypoxia model. Biol Res 49: 7.

5. Ng KTP, Guo DY, Cheng Q, Geng W, Ling CC et al. (2012) A Garlic Derivative, S-allylcysteine (SAC), Suppresses Proliferation and Metastasis of Hepatocellular Carcinoma. PLoS ONE 7(2): e31655.

6. Baiqiang Z, Chuanhai Z, Yao S, Changhui Z, Xiaoyun H et al. (2018) Hypoglycemic and hypolipidemic effect of S-allyl-cysteine sulfoxide (alliin) in DIO mice. Scientific Reports 8: 3527.

7. Chan JY, Yuen AC, Chan RY, Chan SW (2013) A review of the cardiovascular benefits and antioxidant properties of allicin. Phytotherapy Research 27(5): 637-646.

ISSN: 2574-1241

DOI: 10.26717/BJSTR.2018.06.001352

Ashique Ali Arain. Biomed J Sci \& Tech Res

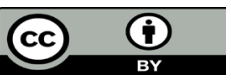

This work is licensed under Creative Commons Attribution 4.0 License

Submission Link: https://biomedres.us/submit-manuscript.php
8. Soo Hyun Park, Hoyoung Lee, Hak Sung Kim, Yong-Ro Kim, Sang Ha Noh (2014) Optimum Conditions for S-allyl-(L)-cysteine Accumulation in Aged Garlic by RSM. Food Sci Bio technol 23(3): 717-722.

9. Ansari MA, Phull QZ, Arain AA, Memon AR, Kazi S, Abbasi P (2017). Comparison between S-Allyl Cysteine and Gliclazide in Lowering the Blood Glucose Levels in Diabetic Rats. J Liaquat Uni Med Health Sci 16(02): 99-102.

10. Rohilla A, Ali S (2012) Alloxan Induced Diabetes: Mechanisms and Effects. IJRPBS 3(2): 819-823.

11. Augusti KT, Sheela CG (1996) Antiperoxide effect of S-allyl cysteine sulfoxide, an insulin secretagogue, in diabetic rats. Experientia 52(2): 115-119.

12. SMA Shariatzadeh, M Soleimani M, M Mehmodi, MH Abnosi, HR Momeni et al. (2008) Effects of garlic and blood glucose and nephropathy in diabetic rats. Journal of biological sciences 8(8): 1316-1321.

13. Sekh Abdul Nasim, Bhupinder Dhir, Rashmi Kapoor, Samar Fatima, Mahmooduzzafar, et al. (2011) Alliin obtained from leaf extract of garlic grown under in situ conditions possess higher therapeutic potency as analyzed in alloxan-induced diabetic rats, Pharmaceutical Biology 49(4): 416-421.

14. Fatma AA, Ariza A, Nor Salmah B, Muhamed TO (2013) Effects of Garlic Oil Administration on Some Immunological Parameters in Induced Type1 Diabetes Mellitus. Journal of Pharmaceutical, Biological and Chemical Sciences 4(2): 1572-1584.

15. Cheng TzuLiu, Tien WeiHsu, Ke MingChen, Ya PingTan, Chong KueiLii, et al. (2012) The Antidiabetic Effect of Garlic Oil is Associated with Ameliorated Oxidative Stress but Not Ameliorated Level of Proinflammatory Cytokines in Skeletal Muscle of Streptozotocin-induced Diabetic Rats. Journal of Traditional and Complementary Medicine 2(2): 135-144.

16. EJ Henriksen, MK Diamond Stanic, Marchionne EM (2011) Marchionne Oxidative stress and the etiology of insulin resistance and type 2 diabetes Free Radical Biology \& Medicine 51(5): 993-999.

17. D Pessler Cohen, PH Pekala, J Kovsan, A Bloch Damti, A Rudich, et al. (2006) GLUT4 repression in response to oxidative stress is associated with reciprocal alterations in C/EBP alpha and delta isoforms in 3 T3-L1 adipocytes Archives of Physiology \& Biochemistry 112(1): 3-12.

18. V Rajani Kanth, P Uma Maheswara Reddy, TN Raju (2008) Attenuation of streptozotocin-induced oxidative stress in hepatic and intestinal tissues of Wistar rat by methanolic-garlic extract Acta Diabetologica 45(4): 243251 . 